\title{
How to Discover Students' Talents and Turn Them into Teaching
}

\author{
JUDr. Michal Urban ${ }^{1}$
}

\section{Introduction}

Some law students were born to teach. Their professors' job is to help them to discover their talents and turn them into teaching. This paper offers a description of the Prague Street Law Programme with an emphasis on the way of working with law students, who possess clear talent for teaching. Students enrolling for Street Law clinics are students of law, who have obviously decided to study law rather than pedagogy. However, when being provided with an opportunity to teach, some law students prove to possess clear pedagogical talents, which they themselves might not realise. This article analyses Czech experience regarding running Street Law clinics, whose aim goes beyond traditional aims of Street Law clinics, i.e. beyond putting theory into practice, looking at law through the eyes of the lay people, communicating legal matters to lay people, improving presentation skills and serving the community. In addition to these highly beneficial traditional aims of Street Law clinics, Prague Street Law programme also seeks to create an environment, in which law students might realise their pedagogical talents, equip them with necessary methodology, find enjoyment in teaching and efficiently turn their talents into the teaching of law. The paper focuses in particular on the description of the way Prague Street Law programme is designed to support the described goals and lists a number of concrete teaching methods, which have been employed to stimulate students' pedagogical development, since these might serve as a source of inspiration for other clinicians. ${ }^{2}$

1 Michal Urban has received his Master degree at Faculty of Law, Charles University, Prague, Czech Republic, as well as Master degree at Faculty of Education, Charles University, Prague (specializing in Teaching of Social Sciences and of English language and literature). Additionally, he has passed his doctoral exam and received the academic title of JUDr. He is currently carrying out his
Ph.D. research at Prague's Faculty of Law regarding legal consciousness and teaching law at secondary schools. He is a teacher of Street Law programme at Prague's Faculty of Law as well as a teacher of law at two Prague grammar schools.

2 In this paper, the terms "faculty teacher" and "clinician" are used as synonyms. 


\section{Standard Street Law Clinic in Prague}

Since 2009, Prague Law Faculty has run the most advanced Street Law programme in the Czech Republic. ${ }^{3}$ The fundamental part of the programme is a standard Street Law clinic, which each semester provides 15 law students with the experience of teaching law at Czech public secondary schools. It is opened every semester for a new group of students from the third, fourth and fifth years. ${ }^{4}$ Younger law students are not allowed to sign up, since they might not yet possess sufficient legal knowledge. Each semester is divided into three equally long periods lasting one month. The first month of the semester is spent at the faculty and the faculty teacher introduces students to the basics of the teaching profession, students learn essential teaching principles, fundamental teaching tricks and they are also encouraged to identify elementary teaching mistakes. The second month is devoted to the teaching practice and law students spend it in participating Prague secondary schools, in which they teach law to pupils aged from 14 and 19 years. The last month of the semester takes place at the faculty and students are required to reflect on their teaching experience and work out a portfolio, in which they summarize and evaluate their teaching experience, describe teaching methods and activities they were using and archive all their lesson plans in case they need them in the future.

The aim of the standard Street Law clinic is similar to the aim of many other clinics, i.e. to make it possible for law students to use their theoretical knowledge of law in practice, learn more about the way lay people understand the law, practise explaining legal matters in a simplified but still true way to lay people, learn team cooperation, improve presentation skills, learn improvisation "on the spot" and eventually also serve the community by taking part in a clinic. Although the standard Street Law clinic has been running only for two semesters, it has became rather popular and draws attention and active participation from many law students.

\section{Upgraded Street Law Clinic}

In reaction to the relative success of the standard Street Law clinic, Prague Law Faculty decided to work with the most talented law students more permanently and establish a sequel to the standard Street Law clinic, which would engage students in a more complex way. Therefore, an upgraded Street Law clinic has been introduced. ${ }^{5}$ In order to find appropriate law students for the clinic, the goal of the clinician, who is teaching the standard Street Law clinic, was expanded to include the following tasks:

1) identify those law students, who are undoubtedly good at teaching;

3 Prague Law School is a faculty of the Charles University, the oldest university in Central Europe, founded in 1348. In comparison with the other three law schools located in today's Czech Republic, which are part of the universities in Brno, Pilsen and Olomouc, the Prague Law School tends to be more conservative, which includes a cautious approach to clinical legal education.

4 Public law schools in the Czech Republic offer only Masters programmes in law, no Bachelor programme in law is available. The Masters programme lasts for five years and is opened to all students, who have graduated from their secondary schools and passed the entrance exams.

5 In this paper, the term "standard Street Law clinic" is used for a basic, fundamental Street Law I clinic, whereas "upgraded Street Law clinic" for an extended version of a Street Law clinic opened only to students, who have graduated from the standard Street Law clinic. This upgraded Street Law clinic might as well be called Street Law II in the faculty's curriculum. Not to confuse these terms, only the longer, more self-explanatory terms are used in the paper. 
2) create an environment in which such students may realise their talents to teach and help them equip themselves with necessary methodology;

3) let such students experience what an unforeseen satisfaction teaching may bring them;

4) and eventually prepare such conditions in which these talented students might continue teaching law even after standard Street Law clinic terminates, ideally even after their graduation from the Law Faculty. ${ }^{6}$

However ambitious the above described upgraded Street Law clinic might appear, all the necessary organizational steps have already been taken and since there is sufficient interest on the students' side, the clinic came into existence in Autumn 2010.7 Since the upgraded Street Law clinic is currently being introduced at the Prague Law Faculty, the paper may unfortunately not present the reader with detailed statistics, which would reveal more about the project's outcome. These statistics will certainly be analysed in a future paper, in which the project will be evaluated and examples of best practice will be presented. As the topic of this paper is to describe the way Prague Street Law clinics work with students with a talent for teaching, there now follows a description of the way of working, which enables the clinic to create a welcoming, motivating, working environment, in which students' talents for teaching might flourish.

The description is divided into six points, which are numbered and always introduced by a short headline.

1) No teaching without pre-school training. Law students are not trained teachers, though some, as argued in this paper, possess a remarkable talent for teaching. Therefore, during the preparatory month at law school, ${ }^{8}$ students are introduced to basic elements of the teaching profession, discuss various educational situations and learn concrete examples of activities they might use in schools. During this pre-school introduction to teaching, two ways to introduce students to the basics of pedagogy are used. First, students are often asked direct, targeted and concrete questions, which force them to think, make use of their past experience, imagine the described situations and develop their pedagogical instinct. Examples of such questions are as follows: What do you do to keep order in the class?, How do you find out whether everybody has understood your instructions? How would you check that pupils have prepared their homework? Each time, several concrete possible answers should be formulated to make sure that students are aware that each of the questions points to a "pedagogical situation", which might be solved in number of ways.

Secondly, all students have to prepare micro teaching session. Each student has to choose any relevant legal topic and prepare a five-minute long "lesson", in which they present this topic to a mock class, which is role-played by the rest of the students in the seminar. ${ }^{9}$ In order to stimulate the atmosphere, students might be given certain roles in the class, such as a role of a "cooperating student", "bored student", "faultfinder" or "student in love with the teacher".

6 We are undoubtedly talking about couple of lessons a week or a month, not full-time teaching, although even full-time teaching may not be fully excluded and some law students might theoretically consider teaching as the main part of their career, be it only for couple of years.

7 This paper had to be submitted in September 2010.

8 In this paper, the term "law school" refers to Prague
Law Faculty, unless otherwise specified in the text.

9 It might appear rather awkward to turn students of law into a class of 14 to 19 year-old-pupils, but as long as the faculty teacher does not fail to stress the play-like character of the activity, the whole roleplay usually is a very enjoyable activity, which most of the law students carry out with unpretentious pleasure. 
Another alternative is to encourage students to design their own roles and ask them to pass their roles to any other student later on. ${ }^{10}$ Despite being full of enjoyment, the activity has a clear educational aim, because it gives students basic feedback on their way of teaching and teaches students to observe their colleagues and provide them with feedback, be it praise or criticism.

2) Keep it intensive. Since the standard Street Law clinic is opened only for a relatively small number of students (up to 15) and lasts only for one semester, strong emphasis is put on the fact that the work with students is intensive. They are required to actively participate in seminars and to work for the whole teaching practice in teams of three, which stimulates cooperation and encourages all members of the team to participate. Seminars take place every week, and when preparing their lessons, students have to meet or consult their plans several times a week.

3) Teams of three: individual performance, yet shared responsibility. For most of the Street Law clinic, students work in teams of three, especially during the teaching practice. The aim is to provide them with somebody to consider their teaching ideas with, to stimulate peer cooperation and peer teaching and to reduce the role of the faculty teacher, who might otherwise find themselves in a role of the final authority, approving every detail of students' lesson plans. The teacher requires a copy of each lesson plan before the lesson is taught, but their role is neither to design nor necessarily fully agree with every activity students have chosen to carry out. The responsibility for the lesson lies primarily on the law students, the teacher should intervene only in cases of "pedagogical emergencies", e.g. when the whole lesson is collapsing, when the lesson plan is clearly badly drafted, or when students are about to touch an extremely sensitive issue either incompetently, or lacking important knowledge about the pupils. ${ }^{11}$ Peer teaching and peer cooperation plays also a significant role in the reflection of each taught lesson.

In order to secure relatively even participation of team members and encourage their activity, students are often given certain roles and take turns in playing them. For instance, during teaching practice, there are always two students who teach the lesson and one who sits at the back of the class and observes the class and his/her teaching colleagues. The job of the observing student is to take notes and once the lesson is over, provide his/her colleagues with precious feedback on their teaching, think about alternative ways of doing activities, of solving educational problems or of organizing the whole lesson. ${ }^{12}$

The division of roles has many benefits. Apart from providing feedback to teaching colleagues, it equally teaches students to observe the class and "read" what happens or might have

10 It is of course very funny, when the card describing the role of a student in love with the teacher is received by someone who would never have thought of being in love with the person teaching at the moment.

11 In one class, for example, one pupil committed suicide a year before the teaching practice of law students. Since the students were preparing a lesson on murder and euthanasia, they were informed about the background of the class. In another case, students planned a clearly boring lesson, which would lead to serious issues between the teaching students and pupils of the class. Therefore, the clinician helped them to improve the lesson.
Otherwise, it is our belief that if students experience some failure during their teaching practice, it mostly stimulates their progress, especially if it happens in early stages of their teaching practice.

12 It certainly helps when observing students are expected to fill in an observation form (preferably a form, which enables them to enter their comments, not just tick boxes or numbers). It not only encourages activity of the observer, but also represents a written piece of feedback, which may by given to the teaching colleagues, stored in their portfolios and available for future study or reflection. 
happened during a lesson. This helps students improve their own teaching abilities and reflect on their own teaching style and strategies. ${ }^{13}$

While working in teams of three, students are naturally forced to cooperate and divide their workload and responsibility for certain tasks, although the final responsibility for teaching the class is still shared by all members of the team. Obviously, students tend to compete with each other and surpass the performance of other team members, which spices up the teaching atmosphere and stimulates better achievement for all involved. Interestingly enough, some teams manage to cooperate so well that their team works almost professionally, which is mostly rewarded by a very positive response from pupils, who especially enjoy times when teaching students interact and elegantly pass the floor from one to the other student.

4) The teacher is always present - and always observing. ${ }^{14}$ Since the Street Law clinic has been designed as an intensive one, law students are almost constantly observed when working with a class. For statutory reasons, the secondary-school teacher is always required to be present in the lesson. ${ }^{15}$ More importantly, in a majority of cases, there is also the faculty teacher present at the lessons taught by law students and each lesson is followed by a thorough, detailed analysis.

An analysis of one lesson might take up to 60 minutes and represents a fundamental part of the Street Law clinic. It provides crucial feedback to the students and allows them to interact directly with the faculty teacher and clarify various educational and legal issues, which are not theoretical, but directly connected to students' experience with law teaching. These analyses are an essential part of the Street Law clinic, since they directly motivate students to improve their performances and help to identify students' strengths and weaknesses. Additionally, the faculty teacher also makes sure that teaching methods used by law students are sufficiently interactive and motivating for pupils.

The analysis usually starts by student-observer summarising the lesson, pointing out its good and bad sides and offering alternative views and solutions. In reaction to that, the teacher offers his/her view, comments on the feedback delivered by the observing student and asks questions regarding methodological issues, content of the lesson, alternative activities etc. In this way, the feedback is very useful for the students and offers them concrete pieces of advice to be used in preparation of future lessons. As will be described in the following point, students are required to

13 It is our experience that students mostly do not realise this. They primarily see themselves as observers, who help their teaching colleagues by being their "third eye", which sees what the two normal eyes do not or could not see. In this regard, it is useful to encourage students to reflect on their role of the observer and let them formulate, in which ways it helps them in their own teaching. Eventually, it is rather disputable who benefits from the observation more, the teaching, or the observing student. This corresponds with the experience of many mature teachers, who confirm that they improve their way of teaching by observing their colleagues.

14 When formulating this headline, the author was inspired by the proverb about the devil that never sleeps.

15 For safety reasons, law prohibits a law student, who has no legal contract concluded with the secondary school, to undertake full responsibility for the pupils and be the only adult person in the class. Therefore, the school teacher, in whose class law students are teaching, retains legal responsibility for the pupils, which is also reflected by the fact that law students are not paid for the time spent in schools and secondary school teachers still receive salaries for lessons taught by "their" law students. Nevertheless, the pay is not high and compensates the teachers for their time, in which they let law students teach in their classes or provide students with reflections on their teaching.

Another issue, which is not dealt with in this paper, is the degree of cooperation between the law students and secondary-school teachers. Should the secondary-school teachers remain passive all the time, or should they co-teach the lessons with law 
improve from lesson to lesson and thorough, personalized feedback plays an important role in this.

5) Thorough lesson-planning is a must. Since students are given thorough feedback on their teaching, thorough and responsible planning for every lesson is demanded. Most groups are easily motivated by the fact that they want to teach well, want to impress pupils and want to receive good comments from the faculty teacher. However, some students have to be motivated by more explicit formulation of what is necessary to be done till the next lesson. Generally, students are well prepared for their classes.

Our overall experience is that some students devote themselves to teaching and some adopt a more relaxed approach, but satisfactory results and improvements are observable in all cases. As has been set out above, as a result of the personal treatment of all students and direct and intensive contact with the clinician, students are expected and required to improve from lesson to lesson. It seems to be fair to add that the majority of them really do.

6) Teaching well in front of one class as well as in front of the whole world. Teaching can hardly be done privately, without others being able to observe it and comment on it, especially since the Street Law clinic is designed to train possible future teachers of law. Therefore, unlike some seminars at the law faculty, where students may remain passive or even anonymous throughout the whole semester, the Street Law clinic is not intended by far for passive and indifferent individuals. Especially, since we are trying to spread the knowledge about the Street Law programme among the general public and intentionally decided to attract the attention of the media. More specifically, in the school year 2009/2010, we managed to publish several articles about the clinic in national newspapers and two reports regarding the clinic were broadcast by Czech Radio. Furthermore, there was a TV report broadcast by Czech Television. ${ }^{16}$ The interest of the media understandably motivates the students, teaches them about the work of the media and enables them to experience how pleasant it is to read about yourself in a newspaper or watch yourself on public television. Additionally, by finding our way into the public media we are trying to cast doubt on the influential slogan that good news is no news. We have understandably not managed to uproot the slogan, but we have managed to let part of the Czech public know that Street Law clinic exists.

After graduating from the basic Street Law clinic, upgraded Street Law clinic is offered to some of the students. The basic idea, on which the upgraded Street Law clinic is built, is to extend the time limit for the clinic, increase the responsibility and independence of the students and reduce the involvement of the teacher. Therefore, the most talented and hard-working students are offered the opportunity to continue teaching under far more demanding circumstances. In the upgraded Street Law clinic, law students are given one whole class of pupils (i.e. around 30 pupils) to teach for one whole school year. ${ }^{17}$ This time, supervision from faculty teacher is only occasional and there is no secondary-school teacher present in the class, as was the case during the standard Street Law clinic.

students? Benefits and drawbacks of this street law model certainly deserve an analysis.

16 Even though the report is in Czech, some of the readers might appreciate it and therefore we insert its link below. It deals with a moot court the law faculty organized for pupils from one Prague grammar school. It may be found in the Internet- accessible Czech TV archives, the report was broadcast as a part of the evening news, at about 20:19. The address is as follows: http://www.ct24. cz/vysilani/2010/05/09/210411020000509-20:00 zpravy.

17 In the faculty's curriculum, the upgraded Street Law clinic is designed for at least one semester of 
With this new, intensive Street Law clinic in mind, we may expand the previous six points and add five more points, which will more closely reveal the way we work with the students who are offered the opportunity to enrol into the upgraded Street Law clinic. ${ }^{18}$

7) Teaching is not for everybody. As has been mentioned above, the standard Street Law clinic has many useful aims and is vastly beneficial, even for those students who will never attempt to teach law in the future. The upgraded Street Law clinic is, however, opened only for those graduates of the standard Street Law clinic, who are both skilled and hard-working enough to be offered a year-long cooperation with a secondary school. At this stage of the Street Law programme, it is only fair to admit that this form of clinical legal education is not for everybody and not any law faculty student would fulfil such a responsible commitment. Since the role of both faculty and secondary school teacher is reduced and law students undertake, for instance, responsibility for pupils' progress in the class, more caution is necessary. On the other hand, it should not encourage those students, who will be offered a place in the upgraded Street Law clinic, to consider themselves more than the rest of the law faculty. Nevertheless, it is necessary for a clinician to be fully aware of the fact that such advanced teaching should not simply be offered to any student interested in teaching.

8) Growing through responsibility: As has been suggested above, at this stage of teaching, law students are given one class of pupils (i.e. around 30) to teach two hours a week for the whole school year. It is their duty to plan the lessons, to design and realise a year-long plan for the course, to test students, to find ways to motivate pupils all the year around etc. The idea is that by graduating from the standard Street Law clinic, students possess the necessary pedagogical skills to find their way through the whole year on their own. Understandably, even the upgraded Street Law clinic is still a law school subject, therefore supervision of the faculty teacher is required and the teacher will be open to any requests from the students. One of the abilities students should gain during this course is the ability to ask for help when necessary. Nevertheless, the aim of the designer of this course was certainly not to put too heavy a burden on the shoulders of students, therefore students are expected to teach one class in a pair of two law students, which should keep the element of cooperation, peer teaching and team work in the clinic.

9) Moot courts: While teaching, law students will be required to organize moot courts for their classes and teach certain legal topics in this way. The benefits of moot courts for law teaching have been analysed elsewhere and this paper will therefore not repeat this argument, only two comments will be made. Firstly, most of the benefits of moot courts apply both to law school students and secondary school pupils. Secondly, when organizing moot courts, an emphasis should be put on involvement of elements from outside of the class, i.e. professional judges and attorneys, teachers of the school or other classes from the school acting as the audience or improvised jury. Consequently, moot courts should become events for the whole school and

teaching. In reality, secondary schools often require students to teach one class for the whole school year. Therefore, we use the length of one school year in this paper.

18 In terms of law, law students this time enter into an official part-time contract with secondary schools, which entrusts them with full responsibility for pupils during the lesson (therefore no secondary school teacher has to be present in the class) and entitles them to receive basic salary corresponding to the number of taught lessons. 
should attract the attention of the media and help spread knowledge about the project, which is an aim of the Street Law programme described above.

10) Share what you have learned. While taking part in the upgraded Street Law clinic, students will be offered to participate in leading teaching practices of younger law students. After several months of teaching, older Street Law students ${ }^{19}$ should be prepared to allow younger students into their classes not only for observation, but also for their own teaching practices. As they were in a similar position not a long time ago, older Street Law students share common experience with their younger colleagues and their comments on younger students' teaching and pieces of advice might therefore be especially enriching for their younger colleagues. Understandably, the faculty teacher will have to guide and supervise the teaching practice anyway, but an active involvement of older Street Law students would no doubt ease the teacher's task, not to mention having a positive educational impact on participants of the upgraded Street Law clinic. This fact, after all, corresponds with one of the mottos of all Street Law programmes, which goes as follows: What you hear, you forget, what you teach, you remember.

11) Learn by writing. Because the standard Street Law clinic has been introduced only recently, there is neither a course-book, nor a reader of relevant texts for Street Law students. Our plan is to put such a reader together and invite students of the upgraded Street Law clinic to participate in preparation of the reader, be it in the form of proofreading, editing or identifying relevant texts.

As has been mentioned above, the upgraded Street Law clinic was opened in Autumn 2010, which prohibits the paper from presenting concrete statistical data, which would provide the reader with empirical support for this Street Law clinic. For the time being, there is only entrance data available, documenting the situation at the beginning of the project. It has been explained earlier that the upgraded Street Law clinic is opened only for the most successful graduates of the standard Street Law clinic, on average 5 out of 15 of the students. Out of these 5 , on average 4 accept the invitation for the clinic, which is considered a rather positive response, especially considering all other options in terms of legal practice. It became rather popular for law students in later years of their studies to start working in legal firms, which certainly pays far better than teaching law in public schools.

However, taking part in the upgraded Street Law clinic depends also on the interest of secondary schools in accepting law students as teachers of law and allowing them to teach two lessons a week the whole year round. So far, we have managed to place two pairs of students in two different Prague grammar schools and we are close to an agreement with another grammar school.

Clearly, the presented numbers are relatively small in comparison with the total number of students studying at the law faculty. ${ }^{20}$ Bearing this fact in mind, it seems to be inevitable that Street Law clinics will continue to be offered as voluntary subjects, which may accept only a small percentage of law students. However, unlike in the past, Prague Street Law clinics are now part of

19 Older Street Law students are those students, who graduated from the standard Street Law clinic and participate on the upgraded Street Law clinic.
20 Every year, Prague Law School welcomes from 650 to 800 new students into the first year of study. 
the official law school curriculum and students who enrol onto the clinics are granted credits for their participation. ${ }^{21}$ Additionally, Street Law programme enjoys a relatively stable support from the faculty, and as the interest of both the law students and the secondary schools is rising, we are considering opening the standard Street Law clinic for up to 30 law students every semester in a year or two. In this context, the future of Street Law programme in Prague appears to be rather promising. Hopefully there will be another opportunity to inform the readers of the International Journal of Clinical Legal Education about the Street Law experience from Prague.

\section{Conclusions}

This paper has, in eleven concrete points, described the way the Prague Street Law programme works with law students, who possess a clear talent for teaching. The points were chosen so that they would enable an insight into the Prague Street Law programme and offer both information about Prague Street Law clinics to those, who have been running similar projects, and inspiration for those, who might get inspired by Prague Street Law experience. It has been explained that one of the programme's aims is to establish a more permanent involvement of talented law students in law teaching. The first step in this process is to identify those law students, who would in future be good teachers of law. It has been highlighted that not all law students would make good teachers of law, even if they endeavoured to do so. The paper suggests that being a good teacher does not mean to excel in one specific area, but rather to possess a whole range of skills and abilities, including a basic talent for teaching, necessary rhetorical skills, determination to learn from mistakes, willingness to take teaching seriously and to carefully prepare for the classes, skills to cooperate with others, and the ability to identify and understand the needs, wishes and feelings of pupils. ${ }^{22}$ In terms of the paper's main topic, it is important to point out that as only a small percentage of law students meet the above-described criteria or possess potential to develop these qualities, these students are precious indeed and deserve the special educational care of the teachers.

The paper further suggests that the teacher's role in the context of the described Street Law programme is not only to search for these students, but also to let them experience and realise their talent for teaching, help them enjoy teaching and experience the satisfaction teaching may bring to them. The enjoyment, together with sensitive guiding of the students by the faculty teacher, naturally motivates students to overcome standard teaching difficulties and prejudices against teaching, including the expectation that school pupils are unbearably naughty and uncooperative these days. ${ }^{23}$

The paper expresses the ambition of Prague Street Law clinics to spur a more permanent involvement of law students in law teaching. The presumption of the Street Law programme is that some law students might continue with teaching even after they graduate from the upgraded Street

21 In the school year 2009/2010, students received two credits, beginning from the school year 2010/2011, four credits will be awarded. On average, students need to gather 30 credits every semester, many of which they receive for compulsory subjects, which all students have to pass in order to proceed into the next year of study.
22 The mentioned skills and abilities might of course be expanded and some more might be added.

23 Interestingly enough, all our Street Law students were positively surprised both by the behaviour and learning motivation of pupils. This should not suggest that all Czech pupils are little angels, but that pupils at cooperating Prague grammar schools are generally a pleasure 
Law clinic and possibly also after their graduation from law school, be it only for couple of hours every month or semester. The paper assumes that not all Street Law students will be willing to give up teaching which they were deeply involved in, which they greatly enjoyed and which was earning them the respect of others, since these benefits might not be easily and adequately substituted by work in a legal office. Nevertheless, the paper concludes that for presenting detailed empirical data the Prague Street Law programme is still too young. 
